\title{
REVIEW OF THE SURVEY'S ACTIVITIES IN 1972
}

\section{K. Ellitsgaard-Rasmussen}

\section{Director}

In 1972 the Geological Survey of Greenland (GGU) continued activities in Greenland on the same scale as in the previous year, with a total of 127 people travelling to Greenland from Copenhagen to take part in geological, glaciological and geophysical work in eight major areas. The Survey, in its capacity as the official government department of the Ministry for Greenland dealing with geological affairs, carries out a variety of tasks involving geological mapping and prospecting, specialised investigations and the evaluation of potentially economic sites, as well as advising the Ministry on a number of matters concerning concession rights for mineral and hydrocarbon exploration and extraction.

With the continuing steady increase in interest surrounding the mineral and hydrocarbon potential of Greenland, considerably more emphasis is being placed on economic matters. With this development the inevitable reorganisation of the internal structure of the Survey has begun and has been heralded by the formation of a section dealing with oil and gas geology to join the much larger mapping department. Other sections are expected to follow as the Survey grows steadily larger in the coming years.

\section{Personnel}

1972 saw a substantial increase in the number of permanent staff based in Copenhagen, the Survey being served by 22 geologists and 1 chemist. Laboratory, technical and administrative staff numbered 52. As in previous years a large number of scientific personnel and supporting crews were on contract with the Survey for summer field work in Greenland from June to September.

Out of the total of 127 expedition members working in Greenland 53 were geologists and 5 were senior students. Geology students acted as field assistants. A number of Greenlanders participated in the field work, either as field assistants or as crew members on GGU ships.

\section{Operations in Greenland}

The major areas of Survey operations in 1972 are shown in fig. 1. Field parties were flown from Copenhagen to airports at Søndre Strømfjord, Narssarssuaq and Mesters Vig in West, South and East Greenland respectively, from where travel continued to field and base camps by helicopter and fixed-wing aircraft or by 
ship. One geophysical party travelled direct to West Greenland with the chartered Norwegian sealer "Brandal". Transport during the field operations was by helicopters owned by the Survey and Heliswiss A/G, Bern, a Pilatus Turbo Porter from Air Glaciers, Switzerland, as well as by Survey ships, motor-boat and jeeps.

Field projects undertaken can be assigned to six main groups concerned with:

(a) geological mapping aimed at publication of 1:100 000 map sheets,

(b) geological mapping at various scales,

(c) Quaternary investigations,

(d) geophysical investigations,

(e) economic investigations,

(f) specialised projects.

(a) In central West Greenland the previous years mapping of the Tertiary lavas and sediments was continued on Disko and Nûgssuaq.

In central and southern West Greenland the detailed regional mapping of the Precambrian basement was continued with the first year of the Buksefjorden project in the region south of Godthåb and with the third year of the helicoptersupported project around Fiskenæsset.

In the Scoresby Sund region of East Greenland, the five year project within the Caledonian fold belt was successfully concluded.

(b) Detailed mapping on specialised topics was carried out on the Tertiary sediments of Nûgssuaq, on the Nagssugtoqidian deformed rocks of the Holsteinsborg-Søndre Strømfjord region, on the Archaean complex of the Godthåb district, on the sapphirine-bearing rocks of the Fiskenæsset region and in the Ilímaussaq alkaline intrusion of South Greenland.

(c) Mapping of Quaternary deposits was carried out in the region south of Disko Bugt in West Greenland while in East Greenland glaciological studies were undertaken in the Scoresby Sund region.

(d) This year geophysical work included both offshore and onshore activities.

The West Greenland sedimentary basin was the site of a shipborne magnetic and seismic programme which ran concurrently with onshore gravity and magnetic measurements; these projects were aimed at providing details on the relationships of sediments and volcanics in the basin.

Sampling for palaeomagnetic studies was carried out on the Precambrian basement in the Fiskenæsset, Søndre Strømfjord and Godthåb regions and on the Tertiary lavas in the Scoresby Sund area of East Greenland; some measurements were made using a portable magnetometer.

(e) In the course of the basic geological mapping considerable information on economic aspects is assembled; geiger-counter readings are systematically registered and any mineralisations and deposits of possible economic importance are recorded and assessed. In addition a small party made a systematic collection of ore 


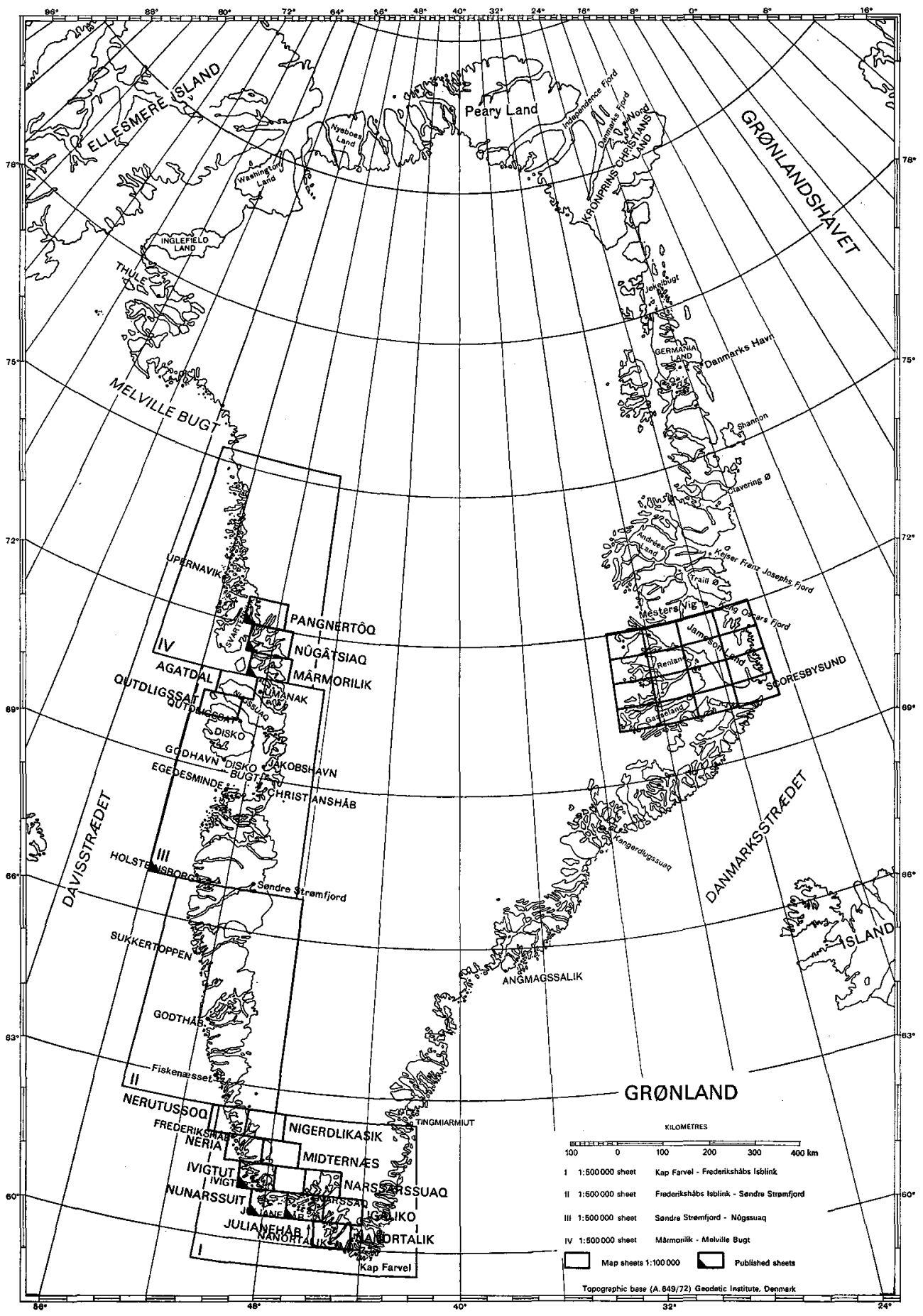

Fig. 2. Greenland showing the map sheets issued and in preparation by the Survey. 
minerals, mainly sulphides, from the Ilímaussaq alkaline intrusion of South Greenland.

The geophysical work in the West Greenland basin noted above is geared to the economic potential of the region. Calculated depths to basement and estimates of composite sedimentary thicknesses from the geophysical work contribute to the assessment of hydrocarbon potential. In connection with the geophysical work a shallow-core drilling programme was carried out on Nûgssuaq as a continuation of the drilling activity started last year.

In East Greenland, a preliminary assessment of the hydrocarbon potential of selected Upper Palaeozoic and Mesozoic sections was made during the summer and samples were collected for oil source rock analysis.

(f) Studies on a number of specialised projects were carried out in the Ilímaussaq intrusion of South Greenland. These included the detailed geochemistry of the major rock types and selected mineral phases, the geochemistry of sea, river and lake waters, and the detailed structure of lujavrite.

Samples were collected in the Godthåbsfjord and Fiskenæsset regions for a variety of geochemical investigations.

In addition ground temperature measurements have been recorded throughout the year at stations set up at Holsteinsborg, Søndre Strømfjord, Jakobshavn and Godhavn.

\section{Collaboration with other institutes}

By employing summer contract geologists, geophysicists and other personnel, both Danish and foreign, the Survey enjoys a fruitful collaboration with many geological institutes. The material collected in Greenland under GGU auspices forms the basis of numerous research projects. Contact is encouraged and maintained with other institutions interested in Greenland so that maximum benefit can be obtained from the sharing of resources and exchange of ideas.

In Denmark close cooperation with the Mineralogical Museum and the Mineralogical-Geological Institutes of the University of Copenhagen, the Danish Atomic Energy Commission and the Geotechnical and Mineralogical Institutes of the Technical University in Copenhagen, has continued, and a sharing of laboratory equipment and personnel with the University of Copenhagen has proved most beneficial.

In 1972, the Survey's staff were joined in the field by scientists from these Danish institutions and from the universities of Bergen, Exeter, Geneva, Helsinki, Lausanne, Liverpool, London, Leicester, Manchester, St. Andrews, Southampton, Utrecht and from Carlton University, Ottawa, as well as from Trinity College in Dublin, Portsmouth Polytechnic, Geological Survey of Czechoslovakia, Eigd. Technische Hochschule in Zürich, Geological Survey of Canada, and Olexcon International N.V., The Hague.

The Survey's capacity for geochemical work is relatively limited when compared 
with the number of geologists now active in Greenland. This deficiency was remedied by collaboration with the universitites of Birmingham, Durham and Leeds to raise the output of chemical data. Likewise the universitites of Copenhagen, Geneva, Minnesota, Oxford, Sheffield and Leeds, the Eidg. Technische Hochschule in Zïrich, the Geophysical Laboratory of the Carnegie Institution, Washington and the Scottish Research Reactor Centre have provided isotopic age determinations on Survey rock material. Shells, wood, bone and peat have been dated through cooperation with the National Museum of Copenhagen, University of Washington, and Isotopes Inc., New Jersey.

Throughout the year Survey geologists continued to contribute to international conferences and symposia and meetings were attended in Berkeley, Bristol, Edinburgh, Exeter, Galicia, Keele, Leiden, London, Madrid, Manchester, Montreal, Newcastle, Oslo, Tömte and Trondheim.

\section{Publications}

In 1972 compilation continued on the $1: 500000$ and 1:100000 geological maps series. Of these a single 1:100 000 sheet, Julianehåb $60 \mathrm{~V} .2 \mathrm{~N}$, was published, while the drawing of Midternæs and Agatdal were finished in manuscript form. Work on the sheets Neria, Nigerdlikasik and Nerutussoq is well advanced.

The first of a series of 1:500 000 Quaternary maps of West Greenland was completed in manuscript form.

Detailed maps of selected areas at various scales continued to form an important part of the Survey's publications and these were published as illustrations accompanying written publications. In 1972, Bulletins (also part of Meddelelser om Gronland) 98 to 103, Reports 41 to 49 and Miscellaneous Papers (reprinted from international journals) 98 to 103 were published.

Continued interest in the hydrocarbon potential of the West Greenland sedimentary basin has led to the production of a new bathymetric map series at 1:100 000 covering the west coast and neighbouring marine areas between $59^{\circ} \mathrm{N}$ and $73^{\circ} \mathrm{N}$.

In addition a number of occasional publications were issued, which included information concerning concessions and prospecting licences granted by the Ministry for Greenland.

\section{Mining and exploration}

The Survey continued to advise the Ministry for Greenland on exploration and mining aspects. By the end of the year 55 companies or groups of companies held prospecting licences from the Ministry for Greenland, three of which were issued in 1972. About $40 \%$ of these licences concerned exploration for oil and gas. Extraction rights in respect of minerals have been given to 4 companies.

Geophysical data received from oil companies was interpreted throughout the year by the Survey's oil and gas section under arrangement with the Survey's 
geophysical consultants, NEGEM Ltd., London, and Olexcon International N.V., The Hague.

Survey members have assisted companies holding concession rights with maps and other basic material as and when requested. The Survey's report archives containing results and notes of field work undertaken by the Survey is available to companies for reference.

In cooperation with the Danish Atomic Energy Commission's Research Establishment at Ris $\phi$, work was continued on the evaluation of the radioactive mineral content of the Ilímaussaq alkaline intrusion in South Greenland as well as on the processing and interpretation of aeroradiometric data in terms of radioactive mineral distribution in the Scoresby Sund region of central East Greenland.

Note

The following 18 articles report the principal field activities in Greenland in 1972, together with the main results of isotopic age determination work carried out on Survey material during the year, and with other laboratory investigations. Articles dealing with North Greenland and central West Greenland come first, followed by those from southern West Greenland, South Greenland and East Greenland. Compilations of isotopic work and radiocarbon dating on material throughout Greenland conclude the report.

Unless otherwise stated at the end of each article, the author's address is the Survey's headquarters in Copenhagen.

\section{ORDOVICIAN AND SILURIAN FAUNAS FROM NORTHERN PEARY LAND, NORTH GREENLAND}

\section{Merete Bjerreskov and Valdemar Poulsen}

Fossiliferous samples were collected from the North Greenland fold belt by P. R. Dawes and N. J. Soper during reconnaissance mapping in 1969. In a preliminary report (Dawes \& Soper, 1970) an Ordovician age was suggested for graptolite shales at O. B. B $\emptyset$ ggild Fjord and Harebugt, the age being based on faunal content, and the association with intraformational limestone breccias bearing a striking resemblance to the Ordovician succession in the western part of the fold belt in Nyeboe Land. A shelly fauna from Frederick E. Hyde Fjord was referred to the Silurian.

The fossiliferous samples were presented to the present authors for further study. This report summarises the fauna from Dawes \& Soper's (1970) localities F1 to F5. 